\title{
The Implementation of Community Partnership Program to Improve the Quality of Online Learning during the Covid-19 Pandemic
}

\author{
Suparman ${ }^{1, *}$, Iwan Hartadi Tri Untoro ${ }^{2}$, Suwadi ${ }^{3}$, Anggit Prabowo ${ }^{1}$, Andriyani ${ }^{1}$, \\ Eko Setyo Humanika ${ }^{4}$, Yahya Hairun ${ }^{5}$, Mahyudin Ritonga ${ }^{6}$ \\ ${ }^{1}$ Department of Mathematics Education, Faculty of Teacher Training and Education, Universitas Ahmad Dahlan, Yogyakarta, \\ Indonesia \\ ${ }^{2}$ Faculty of Information and Electrical Technology, Universitas Teknologi Yogyakarta, Yogyakarta, Indonesia \\ ${ }^{3}$ Faculty of Tarbiyah and Teacher Training, Universitas Islam Negeri Sunan Kalijaga, Yogyakarta, Indonesia \\ ${ }^{4}$ Faculty of Humanities, Education and Tourism, Universitas Teknologi Yogyakarta, Yogyakarta, Indonesia \\ ${ }^{5}$ Faculty of Teacher Training and Education, Universitas Khairun, Ternate, Indonesia \\ ${ }^{6}$ Faculty of Islamic Studies, Muhammadiyah University of West Sumatera, Padang, Indonesia
}

Received August 30, 2020; Revised September 30, 2020; Accepted November 1, 2020

\section{Cite This Paper in the following Citation Styles}

(a): [1] Suparman, Iwan Hartadi Tri Untoro, Suwadi, Anggit Prabowo, Andriyani, Eko Setyo Humanika, Yahya Hairun, Mahyudin Ritonga, "The Implementation of Community Partnership Program to Improve the Quality of Online Learning during the Covid-19 Pandemic," Universal Journal of Educational Research, Vol. 8, No. 11B, pp. 6134 - 6138, 2020. DOI: 10.13189/ujer.2020.082249.

(b): Suparman, Iwan Hartadi Tri Untoro, Suwadi, Anggit Prabowo, Andriyani, Eko Setyo Humanika, Yahya Hairun, Mahyudin Ritonga (2020). The Implementation of Community Partnership Program to Improve the Quality of Online Learning during the Covid-19 Pandemic. Universal Journal of Educational Research, 8(11B), 6134 - 6138. DOI: 10.13189/ujer.2020.082249.

Copyright@2020 by authors, all rights reserved. Authors agree that this article remains permanently open access under the terms of the Creative Commons Attribution License 4.0 International License

\begin{abstract}
The COVID-19 pandemic has an impact on the teaching and learning process in schools, which was initially carried out face-to-face under normal conditions. This research aims to determine the effect of community partnership programs on mathematics teacher's ability to develop the right online learning tools for students during the Covid-19 pandemic. This is a non-experimental pretest/post-test research with the sample population consisting of a total of 47 teachers of Muhammadiyah junior high school in Sleman Regency, Indonesia. The purposive sampling technique was used to obtain data from 21 mathematics teachers of the sample population through a questionnaire and analyzed using the paired sample t-test. The results showed that there are differences in the teacher's ability to develop Subject Specific Pedagogy (SSP) based on the Learning Management System (LMS) before and after receiving training. Furthermore, the results of the paired sample t-test show that teacher's ability to develop LMS-based SSP improved after training. This study concludes that the Community Partnership program can effectively improve teachers' ability to manage the
\end{abstract}

mathematics learning process online. The novelty of this study is to integrate SSP into online learning using a LMS. This online learning can be a solution when face-to-face learning cannot be done, for example during the COVID-19 pandemic.

Keywords Learning Management System, Mathematics Learning, Subject Specific Pedagogy

\section{Introduction}

Information and Communication Technology (ICT) is one of the important skills that need to be possessed by every 21st-century teacher. Information literacy is not the focus of schools [1]; however, literacy is important for students and a fundamental human right [2]. Over the past decade, there have been extensive investments to stimulate ICT-supported flexible learning [3]; learning media, computing, and communication tools should be more 
creatively and innovatively used [4]. It also has potential in learning management, with the ability to increase efficiency, improve the quality of teaching and learning, enhance skills, and present a more modern learning appearance to create a fun atmosphere. The use of ICT deepens material understanding for students; therefore, it is important to embed the concept of computer visualization to certain topics in mathematics [5]. ICT can also be used as a means of distance learning for instance, during the Covid-19 pandemic it was one of the solutions used in maintaining the continuity of teaching and learning processes in schools.

However, not all teachers can optimize its use as a medium for managing classroom learning. The Focus Group Discussion (FGD) with mathematics teachers in several junior high schools showed that some teachers are familiar with the use of Ms. Office applications such as Word, Excel, and PowerPoint, with the inability to optimally explore and package them in Learning Management System (LMS). Some of the findings in these schools were teachers' inability to (a) carry out e-learning classes using LMS and (b) attend training or similar activities regarding e-learning class making. The following findings were obtained on learning tools: (a) some teachers have not developed specific subject pedagogy (SSP) and (b) some have not packaged learning tools as content in e-learning.

Based on these FGDs, this study concluded that there are two aspects of teacher abilities that require attention. Firstly, the teacher's ability to learn using Learning Management System (LMS) still needs to be improved, in order to manage the subject matter creatively and interactively according to the level of student development. This ability enables teachers to build their ICT-based learning tools according to their needs without relying on providers from other parties. Therefore, the independence of this ability is needed to ensure that teachers can create LMS-based e-learning classes, especially with the inception of the Covid-19 pandemic. Secondly, the teacher's ability to prepare learning tools in the form of SSP, namely: syllabus, lesson plans (RPP), teaching materials, student worksheets, and assessment sheets also need to be improved.

Based on situations and conditions analysis that have been previously described, problems faced by teachers can be identified regarding the development of learning tools as well as the teaching and learning process management. The first problem is teachers' ability to use various LMS such as the internet to make rosters, manage documents, distribute learning notes to students, schedule courses, engage classes, assign grades, make registrations, and test/certification as a medium for managing mathematics learning. The second problem is the teacher's ability to design specific subject pedagogy as LMS content by developing a syllabus, lesson plans, student modules, work, and assessment sheets. Furthermore, they still need to be monitored and assisted to ensure they can compile and implement the use of ICT in classroom learning independently.

To solve the problems above, this research conducted a literature survey to determine relevant theories as a basis for providing solutions. Various previous studies have integrated Information and Communication Technology (ICT) in learning, for example, [3], [6], [7]. Teacher training in using ICT in education management needs to be improved [3]. Integrating ICT into teaching and learning can be carried out through the use of blogs, communication applications, online educational games, online learning management systems, online searches for information and educational videos [6]. Media literacy needs to be integrated into the curriculum to improve digital competence for both educators and students [7].

Based on the literature survey results, a community partnership program was created for junior high school mathematics teachers to train and assist them in optimizing ICT learning tools. Firstly, the problem of teachers' uneven ability to utilize technology and communication for teaching and learning management is enhanced through training in the use of the Learning Management System (LMS). These include using the internet to make rosters, manage documents, distribute learning notes to students, schedule courses, engage classes, assign grades, make registrations, and test/certification. Secondly, the problem of low teachers' ability in preparing mathematics learning tools is enhanced through training in the form of Subject-Specific Pedagogy (SSP), which includes: developing syllabus, lesson plans, student modules, work, and assessment sheets.

This research aims to determine the effect of community partnership programs on teachers' ability to develop online learning tools on a specific subject pedagogy using the Edmodo platform.

\section{Methodology}

In accordance with Suparman et al. [8], this article uses a non-experimental pretest/posttest design, as shown in Figure 1.

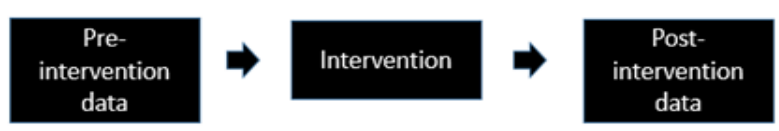

Figure 1. Non-experimental pretest/ posttest design

The research provides treatment in the form of training and compares the teacher's ability to develop a subject-specific pedagogy based on a learning management system before and after the training. The research purpose is to determine whether there is an effect of training on the ability of teachers before and after being given training. The hypotheses formulation are as follows:

$\mathrm{H}_{0}$ : There is no mean difference between pretest and posttest scores

$\mathrm{H}_{1}$ : There is a difference in the mean pretest and posttest scores 
An online learning platform is used to carry out this training to facilitate teachers sharing experiences regarding the use of ICT for teaching and learning [9]. The training materials include: (a) internet utilization in learning, (b) the use of LMS, (c) developing syllabus, (g) lesson plans, (h) student worksheets, (i) modules, and (j) an assessment instrument.

The research population was 47 teachers of Muhammadiyah Junior High Schools in Sleman, Indonesia, with 21 mathematics teachers selected through the purposive sampling method. Data collection was carried out from August 3 - 8, 2020 on teachers' abilities to develop subject-specific pedagogy and learning management systems, using test questions. The data analysis technique was descriptive statistics and paired sample t-test.

\section{Result and Discussion}

Data collection was carried out before and after the training by testing the participants. The items contain several questions including the teacher's ability to: (a) compose a subject-specific pedagogy, and (b) create e-learning classes using a learning management system with the Edmodo platform. The lists of questions are shown in Tables 1 and 2. Table 1 presents a list of questions regarding SSP.

Table 1. Questions List Regarding SSP

\begin{tabular}{cl}
\hline No & \multicolumn{1}{c}{ Question } \\
\hline 1 & According to process standards, learning designed by teacher needs to be adjusted to graduate competency and content standards. \\
2 & Mention the learning principles according to these two standards! \\
3 & $\begin{array}{l}\text { The reference for preparing a learning framework for each subject study material is an understanding of.... } \\
\text { school, class, and subject level means.... }\end{array}$ \\
4 & The specific abilities including attitudes, knowledge, and skills related to content or subjects means.... \\
5 & $\begin{array}{l}\text { A Lesson Plan (RPP) is a face-to-face learning activity plan for one or more meetings. The lesson plan needs to pay attention to } \\
\text { certain principles. Mention 4 principles in preparing RPP! }\end{array}$ \\
7 & What are the teaching materials? \\
8 & What is the purpose of preparing teaching materials? \\
9 & In developing teaching materials, it is necessary to refer to the development principles. Mention the principles of developing teaching \\
10 & materials! \\
\hline
\end{tabular}

Meanwhile, Table 2 presents questions regarding LMS.

Table 2. Questions List Regarding LMS

\begin{tabular}{cl}
\hline No & Question \\
\hline 1 & The learning microblogging platform used by teachers and students, with access provided to parents to monitor student activities is..... \\
2 & The following are not the benefits of the Edmodo Platform .... \\
3 & The picture above is one of the views in Edmodo which to..... \\
& The features in Edmodo intended for uploading teaching materials are.... \\
& Accounts are set up in Edmodo through .... \\
6 & To create a student account on the Edmodo Platform, the... button is clicked. \\
7 & The......feature is clicked to make an assignment on Edmodo. \\
8 & The steps for reading the subject matter in Edmodo are.... \\
9 & User Parent in Edmodo is used for.... \\
10 & The space for making notes to be printed on Edmodo's "Home" page, for all students to read is ..... \\
11 & Explain what you understand about Edmodo! \\
12 & What are the advantages of the Edmodo Platform for classroom learning capable of attracting users! \\
13 & Give your opinion on the suitability of the Edmodo Platform compared to other platforms for online learning alternatives during the \\
\hline
\end{tabular}


The test results before and after training are shown in Table 3.

Table 3. The pretest and posttest scores of each training participant

\begin{tabular}{|c|c|c|}
\hline \multirow{2}{*}{ No. Respondents } & \multicolumn{2}{|c|}{ Score } \\
\hline & Pretest & Posttest \\
\hline 1. & 36.67 & 83.33 \\
\hline 2. & 66.67 & 85.00 \\
\hline 3. & 40.00 & 90.00 \\
\hline 4. & 33.33 & 95.00 \\
\hline 5. & 55.00 & 75.00 \\
\hline 6. & 55.00 & 76.67 \\
\hline 7. & 40.00 & 73.33 \\
\hline 8. & 33.33 & 55.00 \\
\hline 9. & 40.00 & 88.33 \\
\hline 10. & 38.33 & 71.67 \\
\hline 11. & 58.33 & 75.00 \\
\hline 12. & 43.33 & 73.33 \\
\hline 13. & 38.33 & 80.00 \\
\hline 14. & 40.00 & 71.67 \\
\hline 15. & 56.67 & 81.67 \\
\hline 16. & 48.33 & 70.00 \\
\hline 17. & 43.33 & 80.00 \\
\hline 18. & 50.00 & 93.33 \\
\hline 19. & 63.33 & 75.00 \\
\hline 20. & 55.00 & 76.67 \\
\hline 21. & 56.67 & 65.00 \\
\hline Mean & 47.22 & 77.86 \\
\hline
\end{tabular}

The pretest and posttest scores in Table 2 show an increase for all respondents. Furthermore, there is an increase of 30.64 in the mean score before (47.22) and after training (77.86), because the learning model used is in accordance with the characteristics of the trainees.

The research utilized the project-based learning with the independent participation of all teachers to produce products in the form of SSP and e-learning classes using LMS with the Edmodo platform. Afterward, the teachers filled out the e-learning class content with SSP with online training using the Edmodo platform. In online training, the authors and trainees were represented by teachers and students. Through this online training, participants can practice the teaching and learning process online as students.

Furthermore, hypotheses tests were used to significantly determine the influence of community partnership programs through LMS-based SSP development training on the difference between the population mean pretest and posttest scores. As written in the methodology section, the hypotheses to be testes are as follows:

$\mathrm{H}_{0}$ : There is no mean difference between pretest and posttest scores

$\mathrm{H}_{1}$ : There is a difference in the mean pretest and posttest scores

These hypotheses were tested using paired sample t-test and SPSS, with the selection in accordance with O'Brien \& Fleming [10]. A paired sample t-test is a general procedure for testing paired data where measurements are carried out continuously.

Before carrying out the paired sample t-test, the normality test of pretest and posttest results data were conducted. Table 4 presents the results of the normality test using Shapiro-Wilk for both pretest and posttest scores at a significance level of 0.05 .

Table 4. Tests of Normality

\begin{tabular}{cccc}
\hline & \multicolumn{3}{c}{ Shapiro-Wilk } \\
\cline { 2 - 4 } & Statistic & df & Sig. \\
\hline Pretest & .925 & 21 & .108 \\
Posttest & .968 & 21 & .699 \\
\hline
\end{tabular}

Table 4 shows that the sig. scores for pretest and posttest are 0.108 and 0.699 , respectively, because the value of both tests is greater than 0.05; therefore, the pretest and posttest scores are normally distributed, which fulfilled the paired sample t-test.

Furthermore, a paired sample t-test was performed using pretest and posttest scores as shown in Table 5.

Table 5 shows that Sig. (2-tailed) the score is 0.000 and less than 0.05 . Therefore, $\mathrm{H} 0$ is rejected and $\mathrm{H} 1$ is accepted, which means that there is a difference in the mean score of pretest and post-test. The hypothesis test results show that there is an effect associated with the development of LMS-based SSP for mathematics teachers of Muhammadiyah junior high school throughout the Sleman Regency.

This training, which is associated with the use of information and communication technology, enables students to learn at home especially during the Covid-19 pandemic. Learning using information technology also has an impact on increasing information literacy for students [11]. The results of this study are in accordance with the results of research in [12]. The use of information technology in learning has an impact on both students and teachers. In addition, the use of technology will help teachers to apply effective pedagogy and foster higher order thinking among students [13].

Table 5 shows that Sig. (2-tailed) the score is 0.000 and less than 0.05 . Therefore, $\mathrm{H} 0$ is rejected and $\mathrm{H} 1$ is accepted, which means that there is a difference in the mean score of pretest and post-test. The hypothesis test results show that there is an effect associated with the development of LMS-based SSP for mathematics teachers of Muhammadiyah junior high school throughout the Sleman Regency.

This training, which is associated with the use of information and communication technology, enables students to learn at home especially during the Covid-19 pandemic. Learning using information technology also has an impact on increasing information literacy for students [11]. The results of this study are in accordance with the results of research in [12]. The use of information technology in learning has an impact on both students and teachers. In addition, the use of technology will help teachers to apply effective pedagogy and foster higher order thinking among students [13]. 
Table 5. Paired Sample t-test

\begin{tabular}{|c|c|c|c|c|c|c|}
\hline & \multicolumn{3}{|c|}{ Paired Differences } & \multirow{2}{*}{$\mathrm{t}$} & \multirow{2}{*}{ df } & \multirow{2}{*}{ Sig. (2-tailed) } \\
\hline & Mean & Std. Deviation & Std. Error Mean & & & \\
\hline Pretest - Posttest & -30.63571 & 13.98831 & 3.05250 & -10.036 & 20 & .000 \\
\hline
\end{tabular}

\section{Conclusions}

The teachers' ability to develop LMS-based SSP improved after the training compared to that before the training. Therefore, this study concludes that the community partnership program has effectively increased the teachers' ability to manage the quality online mathematics learning process in the Covid-19 pandemic.

In accordance with this analysis, schools need to expand teachers' training to other subjects. Therefore, all teachers need to implement quality online learning in the process of teaching and learning activities in class, especially during the Covid-19 pandemic.

Regarding the potential obstacles that teachers find when giving online courses is the language factor. The language used in e-learning tools is English. This will make it difficult for teachers and students who have low English language skills.

\section{Acknowledgements}

The authors are grateful to the Ministry of Research and Technology / the National Research and Innovation Agency, Indonesia, for their financial support through service program grants through the 2020 community partnership program scheme. They are also grateful to the Elementary and Secondary Education Council, the Regional Leaders of Muhammadiyah Sleman (Indonesia) for supporting this community partnership program.

\section{REFERENCES}

[1] H. Ngo and G. Walton. Examining the practice of information literacy teaching and learning in Vietnamese upper secondary schools. Education for Information, Vol. 32, 291-303, 2016.

[2] H. Rahanu, E. Georgiadou, N. Khan, R. Colson, V. Hill, and J.A. Edwards. The development of student learning and information literacy: a case study. Education for Information, Vol. 32, 211-224, 2016.

[3] M. Stigmar, R. Kornefors, and N. Pagden. The modified role of university teachers in ICT-supported flexible learning. Intelligent Decision Technologies, Vol. 6, 113-121, 2012.

[4] R.W. Mwangi, R. Waweru, M. Teranishi, and C.W. Mwathi. Integrating ICT with education: designing an educational computer game for teaching functions in undergraduate mathematics. Journal of Theoretical and Applied Information Technology, Vol. 26, No. 1, 53-63, 2011.

[5] M. Mohammad. Effectiveness Assessment Study of the Use of ICT Tools in E-Learning System. European Scientific Journal, Vol. 10, No. 7, 1857-7881, 2014.

[6] L.Y. Tay, C.P. Lim, S.S. Nair, and S.K. Lim. Online software applications for learning: observations from an elementary school. Educational Media International, Vol. 51, No. 2, 146-161, 2014.

[7] J.A. Young. Assessing new media literacies in social work education: the development and validation of a comprehensive assessment instrument. Journal of Technology in Human Services, Vol. 33, 72-86, 2015.

[8] Suparman, I.H.T. Untoro, A. Prabowo, and Andriyani. The Use of ICT in Mathematics Learning. International Journal of Scientific \& Technology Research, Vol. 8, No. 10, 415-417, 2019.

[9] C.P. Lim, H. Yan, and X. Xiong. Development of pre-service teachers' information and communication technology (ICT) in education competencies in a mainland Chinese university,” Educational Media International, Vol. 52, No.1, 15-32, 2015.

[10] O'Brien, P. C. and Fleming, T. R. A Paired Prentice-Wilcoxon Test for Censored Paired Data. Biometrics, Vol. 43, No. 1, 169-180, 1987.

[11] T. Maitaouthong, K. Tuamsuk, Y. Techamanee. Development of the instructional model by integrating information literacy in the class learning and teaching processes. Education for Information, Vol. 28, 137-150, 2011.

[12] F. Sarsar, Ö.A. Çakir, M. J. Bohórquez, and M. V. Leeuwen. Learners' and Instructors' Views on Technology Supported Engineering Education: Initial Outcomes in a Cross-cultural Study Sample. Universal Journal of Educational Research, Vol. 6, No. 12, 2764-2771, 2018.

[13] M. M. Mokhtar and M. Jamil. Mobile Technology Usage: The Shift of Focus to Cultivate High Level Thinking Skills (HOTS) in the Malay Language Education System. Universal Journal of Educational Research, Vol. 8, No. 1A, 156-163, 2020. 